\title{
Symphonizing Intellectual Property Laws in the Advancement of Culture
}

\author{
Agus Sardjono* \\ DOI: https://doi.org/10.22304/pjih.v4n3.a1
}

\begin{abstract}
The Indonesian Government has enacted the Law on Advancement of Culture. This Law is the manifestation of the trust bestowed by the Indonesian Constitution, entrusting the state to advance the Indonesian culture. This Law is the guideline and ideals for the Indonesian Government and the society at large in conducting efforts to advance culture. The purpose is so that there is a clear direction in the efforts to develop, utilize, promote, and preserve and protect Indonesian culture in the face of globalization and digitalization of world culture. At the very least, this law facilitates individuals who are part of the society, to be more creative in their art and to be rewarded through rights protection. The existence of these two types of laws must create a favorable environment in the efforts of advancing culture. Like an orchestra displaying a beautiful symphony, intellectual property laws and the law of cultural advancement are also a beautiful symphony in the framework of advancing Indonesian culture in hopes for it to provide an important contribution in human civilization. This paper tries to express how the efforts to symphonize the two laws must be done in an assessment that is prescriptive doctrinal.
\end{abstract}

Keywords: advancement, culture, intellectual property, IP law, symphonize.

\section{Simfonisasi Hukum Kekayaan Intelektual dalam Pemajuan Kebudayaan}

\begin{abstract}
Abstrak
Pemerintah Indonesia telah menetapkan Undang-Undang Pemajuan Kebudayaan sebagai bentuk penjelmaan kepercayaan yang diberikan oleh Konstitusilndonesia kepada negara untuk menjadi pelaksanaan pemajuan kebudayaan Indonesia. UU tersebut merupakan pedoman serta cita-cita Pemerintah Indonesia dan masyarakat dalam upaya pelaksanaan pemajuan kebudayaan, dengan tujuan sebagai petunjuk dalam mengembangkan, menggunakan, mempromosikan, menjaga, dan melestarikan kebudayaan Indonesia di hadapan globalisasi dan digitalisasi dunia kebudayaan. UU ini juga sekiranya telah memfasilitasi anggota masyarakat untuk menjadi lebih kreatif dalam sisi seni dan turut diberikan perlindungan hak kepadanya. Keberadaan UU ini harus mampu menyediakan lingkungan yang memadai guna mendorong pemajuan kebudayaan. Layaknya suatu orkestra menghasilkan simfoni yang indah, hukum kekayaan intelektual dan hukum pemajuan kebudayaan juga merupakan simfoni peraturan dalam mewujudkan pemajuan kebudayaan Indonesia guna memberikan kontribusi penting dalam kehidupan manusia. Artikel ini akan membahas bagaimana cara simfonisasi hukum kekayaan intelektual dilaksanakan dalam perspektif doktrin hukum.
\end{abstract}

Kata kunci: pemajuan, kebudayaan, kekayaan intelektual, HKI, simfonisasi,

PADJADJARAN Jurnal IImu Hukum Volume 4 Nomor 3 Tahun 2017 [ISSN 2460-1543] [e-ISSN 2442-9325]

* Professor of Law, Universitas Indonesia, Jl. Prof. Mr. Djokosoetono, Pd. Cina, Beji, Kota Depok, agussardjono@ yahoo.com, S.H., M.H., Dr. (Universitas Indonesia). 


\section{A. Introduction}

The Indonesian Government has recently adopted the Law for the Advancement of Culture. ${ }^{1}$ The said Law is a materialization of the mandate under the Indonesian Constitution requiring the State to undertake endeavors for the advancement of Indonesian culture. ${ }^{2}$

Prior to that, the Indonesian Government had also amended the Copyright Law, ${ }^{3}$ the Patent Law, ${ }^{4}$ and the Trademark Law, ${ }^{5}$ in an effort to improve the system for intellectual property rights protection not only for the Indonesian nation, but also citizens of other Countries which are members of the WTO, due to their ratification of the Agreement on the Establishment of WTO. ${ }^{6}$

The fundamental question is concerning the manner in which the above mentioned various laws are to be implemented in order to create synergy benefiting the Indonesian nation not merely at the level of effective implementation of the legislation, but even more so in the achievement of the intrinsic objectives (teleological aspect) of the establishment and implementation of such laws in an effective and efficient manner.

Is there in a synergy-based relationship between the above-mentioned IP laws and the Law for the Advancement of Culture? If such relationship does in fact exist, what harmonious steps need to be undertaken towards implementing the said laws thus enabling the Indonesian nation to reap the benefits there from?

The above questions need to be addressed in a manner to obtain correct and accurate answers. A doctrinal research is required in order to arrive at theoretical answers which, in their turn, can be used as reference or guidance in the implementation of the said laws by the bureaucratic apparatus being the focal point of the same. At the same time, such theoretical answers can also help community members understand the potential benefits of implementing the said laws.

The above proposed doctrinal research and theoretical answers would indeed prove to be of little use unless they are accompanied by recommendations for implementation in the form of "offering guidelines and solutions". Accordingly, from the methodological point of view, this article does not take an exclusively legal approach; rather than that, it seeks to identify ways or means of materializing the norms of the laws under observation (prescriptive method).

$1 \quad$ Law Number 5 Year 2017 concerning the Advancement of Culture, (Undang-Undang Nomor 5 Tahun 2017 tentang Pemajuan Kebudayaan/ UU PK 2017).

2 Article 32 paragraph (1) of the 1945 Constitution gives the mandate to the government to advance Indonesian culture amidst world civilization.

Law Number 28 Year 2014 concerning Copyright (Copyright Law).

Law Number 13 Year 2016 concerning Patent (Patent Law).

Law Number 20 Year 2016 concerning Trademark and Geographical Indication, (Trademark Law and GI).

Refer to the main principles of the agreement for the establishment of the World Trade Organization (WTO) in 1994. Indonesia ratified the WTO Agreement under Law Number 7 Year 1994 concerning the Agreement for the Establishment of the World Trade Organization. 
The research process begins with an overview of the text of the articles of the laws concerned, followed by interpretation of the same. Such interpretation is based on rational argument, with grammatical, systematic and historical approach.

From the systematic point of view, discussion begins with an initial understanding of the contents and intent of the Law for the Advancement of Culture, followed by an analysis from the perspective of IP laws and regulations, particularly in view of the provisions directly related to the achievement of the objectives of the Law for the Advancement of Culture. The result of such analysis could be considered as an effort towards symphonizing IP Laws in the advancement of Indonesian culture, which could be potentially useful for the execution of the norms of the said laws by the relevant bureaucracy apparatus.

\section{B. Law for the Advancement of Culture and Intellectual Property Rights}

The Law for the Advancement of Culture was adopted on May 24, 2017 under Number 5 Year 2017, and was promulgated on May 29, 2017 in State Gazette Year 2017 Number 104 (hereinafter briefly referred to as UUPK 2017). The objectives for adopting the said Law include the following: (1) develop the nation's noble values, (2) enrich cultural diversity, (3) strengthen national identity, (4) strengthen national unity and integrity, (5) promote the nation's intellectual life, (6) augment the national image, (7) realize civil society, (8) enhance the people's welfare, (9) preserve the nation's cultural heritage, and (10) influence world civilization, with culture serving as guidelines for national development. ${ }^{7}$

The stated objectives of the above Law must be certainly used as criterion for the Government (the Executive) as well as the community at large in the context of developing, utilizing, promoting and preserving Indonesian culture. All four of the said endeavors were also discussed in a series of meetings in the WIPO forum, specifically in the Inter-Governmental Committee on Intellectual Property Rights and Genetic Resources, Traditional Knowledge, and Folklore (hereinafter briefly referred to as IGC on GRTKF). In other words, the stated objectives of UUPK 2017 are indeed an absolute requirement for a nation in defending itself against the current of globalization, which also form an important part of the endeavors undertaken by other nations in the world through UN forums, particularly the WIPO IGC-GRTKF forum.

Furthermore, objects of culture have also been defined in UUPK 2017 as follows: oral tradition, manuscript, traditional customs, rituals, traditional knowledge, traditional technology, arts, language, folklore games, and traditional sports, or briefly put elements of culture. ${ }^{8}$ All of such elements are essentially the result of the human creative process, will, and work (cipta, rasa, karsa, and karya), referred to in literature as culture. ${ }^{9}$

See Article 4 of UU PK 2017.

See Article 5 of UU PK 2017.

See Article 1 sub-article (1) of UU PK 2017. Read also Koentjaraningrat, Manusia dan Kebudayaan di Indonesia, Jakarta: Djambatan, 1988. 
Results of the human creative process, intent and work can take various different forms. They can be in the form of tangible objects, but they can also take the form of intangible objects. IPR concepts are mainly focused on intangible objects in the form of rights of individuals producing individual creative work. On the other hand, culture itself is essentially the product of a certain group of people which can be part of a certain territory or ethnicity, continuously repeated for many generations thus enabling such group to form its own identity. One of the most readily identifiable examples is language. Language is a means of communication used by a certain group in society within a certain territorial unit and a certain ethnic group which subsequently becomes the identity of such group. For instance, Javanese Language, Sundanese Language, Chinese Language, English Language, German Language, Korean Language, Japanese Language, and so on and so forth. The words Javanese, Chinese, English and German are associated with a specific ethnic group or nation using the language concerned. The fact that certain languages are commonly used by nations all over the world may be the result of certain influences such as colonization, trade, politics, education, and the like.

Another, more complex, example in identifying objects of the advancement of culture is traditional knowledge. Traditional knowledge is held by people within a certain region and ethnicity practiced and passed down from generation to generation which subsequently becomes the characteristic of the group concerned. Let us take for example Subak, which refers to the traditional knowledge of the Balinese community related to the paddy-field irrigation system. The term 'subak' is inherently associated with the community practicing a certain paddy-field irrigation technology, specifically in the region of Bali. People who understand the meaning of the word 'subak' would certainly not claim that 'subak' is from Sunda, because they understand that 'subak' is traditional knowledge which subsequently became part of the Balinese community's 'identity'.

Viewed from the IPR perspective, the object of the advancement of culture in its broad meaning is not limited by international conventions (conventional IPRs) such as patent, trademark, industrial design and the like. In other words, in the IPR perspective, objects of the advancement of culture are the intellectual works of certain larger groups of people becoming the characteristic of such group, or they can also be referred to as communal IPRs (such term being used only for ease of reference to distinguish them from patents, trademarks, industrial designs and the like). It needs to be noted, however, that objects of the advancement of culture as intended in UUPK 2017 are not limited to communal IPRs alone; in fact, they are far broader than communal IPRs. ${ }^{10}$ However, it also needs to be pointed out that endeavors for the advancement of culture can potentially result in the creation of intellectual works which according to the IPR concept are eligible for legal protection

10 The advancement of culture itself is defined as "endeavor for strengthening the resilience and contribution of the Indonesian culture in the midst of world civilization through the protection, development, utilization and guidance of culture". [Unofficial translation] See Article 1 sub-article (3) of UU PK 2017. 
under the IPR regime. It is at this point that the synergy between IPR laws and UUPK 2017 comes into play.

\section{Measures for the Advancement of Culture \\ 1. Taking Inventory}

Any steps for the development, utilization, preservation and promotion of culture should be preceded by recording and documenting objects of the advancement of culture. Such process is referred to as taking inventory of cultural elements. Taking inventory is an important step in the process of the advancement of culture as it can help create a database which in its turn can be useful in the preservation process. Such database is also highly significant from the IPR perspective. For instance, in the patent protection system, prior arts $^{11}$ play an essential part. The database serves as an important source in searching prior arts for research and patent application examination purposes. In the copyright protection regime, the database can be used as a source of inspiration in creative work in arts, literature and science. The images below are to illustrate such point:

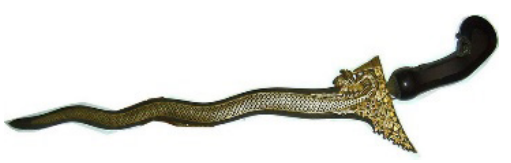

Keris

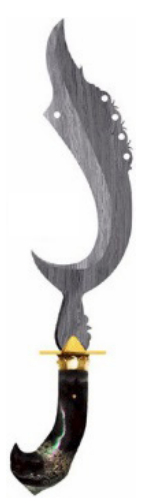

Kujang (Talismanic Sickle)

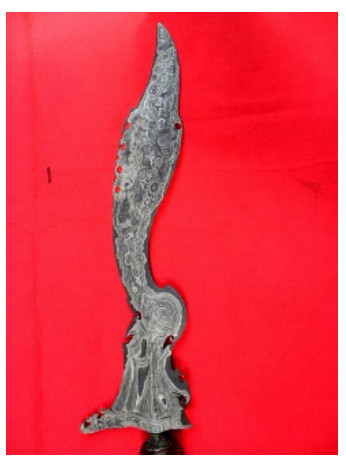

Jangker/Kujang Keris

Keris is a form of art applied to traditional weapons of the Javanese community (even though there are also keris originating from outside the island of Java). At the same time, Kujang is a form of art applied to traditional weapons of the Sundanese community. Both of these two traditional weapons have inspired Hardi in creating a new type of weapon named Jangker, which is a combined acronym of Kujang and Keris. Such inspiration has come from the historic recount of Perang Bubat (The Battle of Bubat) which had caused a rift between the Sundanese and the Javanese community. Hardi strives to reconcile the cultural sentiment of the Sundanese and the Javanese community through the traditional weapons design which he then

11 Prior arts under the patent system is defined as publicized technology, as a criterion for measuring or determining whether or not the invention being applied for patent protection can still be considered as new. Article 3 paragraph (1) and Article 5 paragraph (1) of the Patent Law reaffirms the role of prior arts in the patent protection system. 


\section{decided to call Jangker. ${ }^{12}$}

The question that arises is who should be responsible for taking inventory of cultural objects? It is expressly stated in Article 18 paragraph (1) of UUPK 2017 that 'anyone' can record and document objects of the advancement of culture. It means that the Law grants the liberty to anyone to conduct recording and documentation activities. However, in order to ensure that the objects recorded and documented by 'anyone' are truly cultural elements of the custodian community concerned, there is a need for verification and validation to affirm that the results of such recording and documentation are true and that they can be accounted for. ${ }^{13}$

The process of taking inventory consists of 3 (three) main activities, namely as follows: (1) recording and documentation, (2) determination, and (3) data updating. ${ }^{14}$ Accordingly, the process of taking inventory is a dynamic activity. It is in line with the nature of cultural elements, which are equally dynamic. The overall process is implemented through an Integrated Cultural Data Collection System. ${ }^{15}$

While basically leaving it open to anyone to conduct recording and documentation, in order to ensure that there are parties actually conducting such recording and documentation of object for the advancement of culture, the Law requires the Government, both the Central as well as the Regional Government, to undertake recording and documentation. ${ }^{16}$ It is expected that by the Government undertaking such activities, a unified and standard system of integrated cultural data would be created. Private parties conducting recording and documentation activities can refer to the system developed by the Government, which could facilitate the verification and validation process prior to stipulation by the Government.

Such data verification and validation process must also be applied to the data updating activity, hence it is expected that the integrated cultural data itself will become a standard and valid reference for Indonesian cultural data. Such cultural data would subsequently serve as a useful source for creative people in creating intellectual works in the field of arts, literature, science, as well as technology. All of the foregoing is very closely related to the intellectual property law system which is focused on individual and "new" works (the term is used only to distinguish them from traditional works). That is why there is an absolute need for symphonizing the implementation of the law on the advancement of culture with IPR laws.

\section{Development}

UUPK 2017 gives mandate to the Government to undertake activities for the

12 Hardi is a painting artist who has created Jangker, inspired by the shape of keris and kujang. He currently lives in Jakarta. The author is a personal acquaintance of Hardi, who has described the process behind the creation of Jangker and the process of actually producing the Jangker. See Hardi, "Pusaka Ksatria Nusantara Abad 21: Jangker", http://pelukishardi.com/jangker.html\#.WIVypa6WbIU, accessed on 12 July 2017.

13 Article 19 of UU PK 2017 provides for such validation mechanism through the stipulation process supported by various requirements set forth by the Government by virtue of the law.

14 Article 16 paragraph (1) of UU PK 2017.

15 Article 16 paragraph (2) of UU PK 2017.

16 Article 17 of UU PK 2017 
development of cultural elements. Such activities are also open to anyone carrying out development. ${ }^{17}$ Development activities are implemented through the following endeavors (1) dissemination (publishing or publication), (2) study or research (research and development), and (3) enrichment of cultural elements' diversity. Dissemination is conducted for the purpose of ensuring that culture is not confined within its own territory. Culture needs to be made known to other people outside of its own territory. It can also hopefully contribute to humanity. Similarly, to 'pop culture' which has now spread to almost all corners of the world, it is expected that the wisdom underlying Indonesian culture can potentially make a highly significant and beneficial contribution to humanity.

Research and development of objects of the advancement of culture play an extremely important part in the context of such endeavors. For instance, research and development of traditional knowledge in the area of medicines may potentially result in new discoveries in the field of pharmaceuticals. That being the case, such discoveries are bound to contribute to the development of traditional medicine thus bringing concrete contribution to the area of medicine. In order to accommodate such development, the Patent Law of 2016 already provides for such acknowledgement of traditional wisdom in the area of medicines. Article 26 paragraph (1) of the Patent Law of 2016 reaffirms as follows: "if the invention is related to and/or is derived from genetic resources and/or traditional knowledge, the original source of such genetic resources and/or traditional knowledge must be stated clearly and accurately in the description". [Unofficial translation]

The above quoted provision concerning development is very closely related to the provisions concerning activities for taking inventory of objects of the advancement of culture. In the context of recognizing the fact that there is an invention originating from the development of traditional knowledge, the need for a traditional knowledge database becomes inevitable. Without such database, it is virtually impossible to prove that a certain invention originates from the development of traditional knowledge. In other words, the implementation of activities for taking inventory of objects of the advancement of culture is directly related to the implementation of the Patent Law of 2016. That is why the symphonizing of the implementation of UUPK 2017 with IPR Laws is an absolute requirement.

Furthermore, activities for the enrichment of diversity are endeavors aimed at preserving Indonesia's cultural diversity. In view of the fact that there is a diverse range of ethnic groups, cultural diversity is an indisputable reality. However, enrichment also means the enrichment of various cultures through the process of assimilation, acculturation, adaptation and innovation. It is only through such process that culture becomes increasingly dynamic in keeping up with the developments of time, including developments in science and technology. It certainly raises a question when with all the scientific advancements in the medical field community members

17 Article 30 of UU PK 2017. 
still resort to medical approaches based on superstition, ${ }^{18}$ and the like. Culture is also open to innovation. As the above described case of 'jangker' illustrates, innovation in the design of traditional weapons is also a potential way of enriching certain forms of culture. Thus, endeavors for the enrichment of objects of cultural advancement are essentially also about developing such culture in order to make it resilient in the current of globalization, while bringing the culture of interacting societies into the area of international relations.

The IPR system also has a contribution to offer in the context of enriching objects of the advancement of culture. Traditional music can become increasingly beautiful and interesting to its listeners when innovations and a combination of instruments are introduced in its performance. To illustrate the point, the performance of Megalitikum Kuantum on the $40^{\text {th }}$ Anniversary of Kompas initiated by Rizaldi Siagian is a form of innovation in performing traditional arts. ${ }^{19}$ By making such innovation Rizaldi may in fact become eligible for IPR protection, even though the law for the advancement of culture still requires him to indicate the source, as demonstrated in the above described example of Article 26 of the Patent Law of 2016.

\section{Utilization}

UUPK 2017 opens up an opportunity to the greatest possible extent to community members in Indonesia to utilize objects of the advancement of culture. As evident from the example of traditional knowledge in the field of medicines, every Indonesian citizen is granted an opportunity in the broadest sense to conduct research based on such knowledge, which can potentially result in a patentable invention. However, when applying for the protection of such invention, the inventor or the applicant concerned is required to indicate the origins of his/her invention. ${ }^{20}$ In the field of arts, every person is granted the opportunity to utilize traditional arts as raw materials for their creative work in the modern world. One of the examples in Indonesia is musician Dwiki Dharmawan, who has been using traditional music as source of inspiration in the composition of his creative work in the field of music. Moreover, Dwiki has been successful in touring overseas thus bringing Indonesian traditional music to become part of world music. ${ }^{21}$

UUPK 2017 opens up an opportunity to society at large to utilize objects of the advancement of culture as source for making products. In the example of traditional medicine, the knowledge of custodian communities ${ }^{22}$ can be used as raw materials

18 For instance when it is believed that a person becomes possessed by an evil spirit, and such person is treated by practicing exorcism, and the like.

19 See Uni Sosial Demokrat, “Megalitikum Kuantum, Upaya Menemukan Kembali Indonesia”, , http://www. unisosdem.org/article detail.php?aid=5082\&coid=3\&caid=31\&gid=2, accessed on 13 July 2017.

20 See again Article 26 paragraph (1) of the Patent Law.

21 See Wikipedia about Dwiki Dharmawan, https://id.wikipedia.org/wiki/Dwiki Dharmawan, accessed on 12 July 2017. One of his recent popular recording albums is entitled Pasar Klewer [Klewer Market] produced by Dwiki Dharmawan in collaboration with other world class musicians.

22 The term custodian community refers to a group of traditional community which is the owner or holder of right of cultural expression constituting its identity. In the context of benefit sharing in the utilization of objects for 
or source information in conducting pharmaceutical research, which it in its turn can result in pharmaceutical products, even patent-based pharmaceutical products. As the case of traditional arts illustrations, the arts of custodian communities can be used as material or source of inspiration in creating new works of art, which may potentially obtain Copyright protection. However, objects of the advancement of culture must be used in a manner that does not damage the noble values and wisdom contained in traditional arts underlying them. In addition to that, utilization by large corporations or foreigners must be based on the prior approval of the relevant public authorities. Approval can be granted provided that the following requirements of utilization are fulfilled: (1) approval based on initial information (prior inform consent); (2) there is a benefit sharing (sharing of benefit arising from the utilization); (3) the origins of the object of the advancement of culture concerned are indicated (acknowledgement). ${ }^{23}$

\section{Promotion}

Promotion is an endeavor to introduce Indonesian culture to the world. Similarly to promotion conducted in trade aimed at attracting the interest of buyers to purchase the products offered, the promotion of Indonesian culture is also conducted in order to ensure that Indonesian culture becomes known to other nations in the world, eventually making it attractive to them. Profound attraction would lead to love, while love would create appreciation or respect and it would even potentially lead to using such cultural heritage based products.

Once other nations all around the world become interested in Indonesian culture based products, it is quite likely to lead such a development in the business world such products become the Indonesian nation's premium products. Their characteristic as prime products would be mainly derived from their uniqueness and quality.

In fact, the Indonesian government has formed a non-ministerial institution assigned with the task of promoting creativity of Indonesian nationals through policies in the area of creative economy which, in its turn, is expected to contribute to continuously increasing revenues in the national GDP. ${ }^{24}$ While the creativity of Indonesian nations is based on or finds its source in national cultural heritage, the resulting products also possess competitive edge due to their uniqueness. Provided that such products are developed with adequate quality, they can potentially become attractive to other nations.

the advancement of culture, the custodian community is the recipient of benefit sharing following the utilization of certain objects of the advancement of culture. Refer to the Draft Law concerning Traditional Knowledge and Cultural Expression initiated by the Regional Representatives' Council of the Republic of Indonesia (DPD RI).

23 See Article 37 of UU PK 2017.

24 See Badan Ekonomi Kreatif Indonesia (BEKRAF), "Tugas Badan Ekonomi Kreatif Indonesia", http://www.bekraf. go.id/profil/tugas, accessed on 12 July 2017. 


\section{Preservation}

UUPK 2017 uses the term maintenance to given meaning to endeavor for preservation. Article 24 paragraph (3) of UUPK 2017 states that the maintenance of objects of advancement of culture is aimed at preventing damage, loss or destruction of such objects. It means that preservation is endeavoring to prevent the extinction of the culture of a certain ethnic group. The following is an interesting, but at the same time saddening example. While working on the Megalitikum Kuantum project, Rizaldi recorded music art and Hoho dance performance of the Nias community. ${ }^{25}$ Not long after the recording process had been completed, the catastrophic tsunami disaster occurred on December 26, 2004. Several traditional artists involved in the recording of the Hoho art performance process became victims of the tsunami. One can only imagine what would have happened if the recording process had not been undertaken, while the people practicing the said art are no longer alive; would it not have meant the extinction of such art? That is why recording and documentation constitute a vital part of preservation efforts.

UUPK 2017 requires the Government to undertake endeavors for preservation or maintenance. Similarly, society at large is also granted an opportunity to take an active part the preservation of objects of the advancement of culture. ${ }^{26}$ Such preservation endeavors include the following activities: ${ }^{27}$

a. Safeguard the noble values and wisdom of object of the advancement of culture;

b. Utilize objects of the advancement of culture in everyday life;

c. Safeguard the diversity of objects of the advancement of culture;

d. Revive and safeguard the cultural ecosystem;

e. Pass on the objects of the advancement of culture to the next generation.

Culture can also be preserved through activities for saving objects of the advancement of culture, among other things through activities of revitalization, ${ }^{28}$ repatriation, and restoration. An interesting example of revitalization activities is education and teaching of reading text written in original Bugis language letters. Such activity was initiated when Theatre I La Galigo was put on stage. Theatre I La Galigo itself had been created by Robert Wilson from the United States based on the sacred books of the Bugis people. ${ }^{29}$ The performance raised controversy related to the skillful performance by foreign artists of the epic of La Galigo, although the controversy subsequently calmed down. However, an important lesson was learnt

25 The video on Hoho music and dance performance in the Megalitikum Kuantum project was shown during Kompas $40^{\text {th }}$ Anniversary celebration. Unfortunately, it has been difficult to obtain a copy of the said video. The author has a video recording of Megalitikum Kuantum in the form of softcopy stored on hard disk.

26 Article 24 paragraphs (1) and (2) of UU PK 2017.

27 Article 24 paragraph (4) of UU PK 2017.

28 Revitalization under Law Number 11 Year 2010 concerning Cultural Heritage (Cultural Heritage Law) is defined as "development activities aimed at revitalizing important values of cultural heritage with adjustments to new functions which are not contradictory to the principle of preserving and cultural values of our society." [Unofficial translation] See Article 1 sub-article (31) of the Cultural Heritage Law.

29 See National Geographic Indonesia, "La Galigo Kitab Sakral Orang Bugis", http://nationalgeographic.co.id/ berita/2012/06/la-galigo-kitab-sakral-orang-bugis, accessed on 12 July 2017. 
from the said incident, namely the emergence of the local people's desire to teach reading Bugis letters used in the said sacred Book. Lessons are now being given to young children within the Bugis community in the South Sulawesi region. The said activity is a form of endeavor for the revitalization of the traditional letters of the Bugis language by reassuming activities for the teaching of Bugis letters and language to young children, who may no longer be familiar with the original letters of the said local language.

Repatriation is an endeavor to return cultural objects kept in various countries to the guardian community, or at least to the local museums concerned. On the other hand, restoration is an endeavor to restore cultural heritage objects which may have become damaged due to climate or other conditions. All of the above described activities are essentially endeavors for the preservation of objects of the advancement of culture and for the preservation of the culture itself.

\section{F. The Role of Intellectual Property Laws in the Advancement of Culture}

UUPK 2017 does not limit the responsibility on the Government as executive to undertake important measures for the implementation of the said law. Rather, it also invites all citizens to participate in advancing Indonesia's culture. Such invitation takes the form of providing opportunity to the broadest extent possible to all nationals to under the following activities, among other things:

1) conduct recording and documentation of all cultural elements being the primary targets of the advancement of culture, ${ }^{30}$

2) conduct updating of cultural data, ${ }^{31}$

3) prevent IPR claims by large corporations and foreigners utilizing cultural objects without prior informed consent and sharing of benefit arising from the utilization of Indonesian cultural heritage, ${ }^{32}$

4) prevent damage or extinction of cultural elements, including undertaking all maintenance activities such as safeguarding noble cultural values, introduce innovation of cultural elements in everyday life, for instance by developing the art of batik and using batik as part of everyday clothing, as well as passing on the heritage of all cultural elements to the next generation, ${ }^{33}$

5) undertake revitalization, repatriation and restoration activities involving all cultural elements, ${ }^{34}$

6) undertake activities for the development of cultural elements such as research and innovation. Results of such development activities should be disseminated

Article 1 sub-article (8) jo. 18 paragraph (1) of UU PK 2017.

31 Article 20 paragraph (2) of U UPK 2017.

32 Article 22 paragraph (3) jo. Article 37 paragraphs (1) \& (2) of UU PK 2017. Elements of Indonesian culture are all forms or material manifestation of cultural products of all community groups or ethnic groups which live within the territory of the State of the Republic of Indonesia as well as cultural elements of such community groups expressed outside of Indonesia's territory. The most prominent example of this is when neighboring countries claim Indonesian cultural elements as cultural elements of their own.

33 Article 24 paragraph (3) of UU PK 2017.

34 Article 26 paragraph (3) of UU PK 2017. 
in order to make the public aware that there are new elements of a culture being developed through innovative steps, ${ }^{35}$

7) utilizing cultural elements in the context of building cultural resilience, enhancing social welfare, promoting an active role in the context of international relations, in the economic sector as well as in cross-cultural communications and intercultural collaboration, ${ }^{36}$

All activities undertaken by individuals in the context of advancing culture contain IPR potentials. Let us take for example recording and documentation activities, which can eventually result in the creation of an extremely important database for the purpose of advancing culture. The database itself is a system adopted based on copyright which is an object of copyright protection. ${ }^{37} \mathrm{~A}$ properly verified and validated database is bound to have a very high economic value as its contents can be used as source of inspiration for innovative and creative activities in developing cultural elements.

Furthermore, the development of cultural elements itself can also result in new creations or inventions in the field of technology thus having the potential of resulting in patentable inventions. For instance, research of medicinal herbs used in traditional treatment. Such research can very well result in the discovery of the beneficial characteristics of certain plans thus eventually leading to pharmaceutical inventions of high economic value. Article 26 of the Patent Law of 2016 opens up the possibility to investors to obtain patent protection, provided that prior disclosure of origin is conducted and that it is subsequently followed by benefit sharing if the patent protection creates benefit of high economic value. Such benefit is certainly not limited to profit sharing alone; rather, it can be in the form of other types of benefit in fact much more needed by the custodian community concerned. ${ }^{38}$

In addition to the foregoing, activities of cultural enrichment through cultural innovations can also lead to the creation of products or performance of the creative work of Indonesian nationals of equally high economic value. For instance, an individual by the name of Merdi Sihombing has introduced innovation of traditional textile cloths creating attractive and high-value fashion products. ${ }^{39}$ The images below illustrate a few examples of Merdi Sihombing's abundant creative work in the national culture based world of fashion.

Article 30 paragraph (3) of UU PK 2017.

Articles 32 \& 33 of UU PK 2017.

Article 40 paragraph (1.n.) of the Copyright Law.

This issue is discussed extensively in Agus Sardjono, Hak Kekayaan Intelektual dan Pengetahuan Tradisional, , Bandung: Alumni, 2010.

39 Explore on the Internet: Anis Fuadi, “Merdi Sihombing Usung Kain Tenun Tangan Dari 9 Provinsi”, https://www. senayanpost.com/merdi-sihombing-usung-kain-tenun-tangan-dari-9-provinsi/, accessed on 13 July 2017. See also: Nia Iman Santoso, "Merdi Sihombing, Desaner Tenun Ikut Ulos Indigo di AS", https://www.voaindonesia. com/a/merdi-sihombing-desainer-tenun-ikat-ulos-indigo-di-as---liputan-feature-voa/1884459.html, accessed on 13 July 2017. 


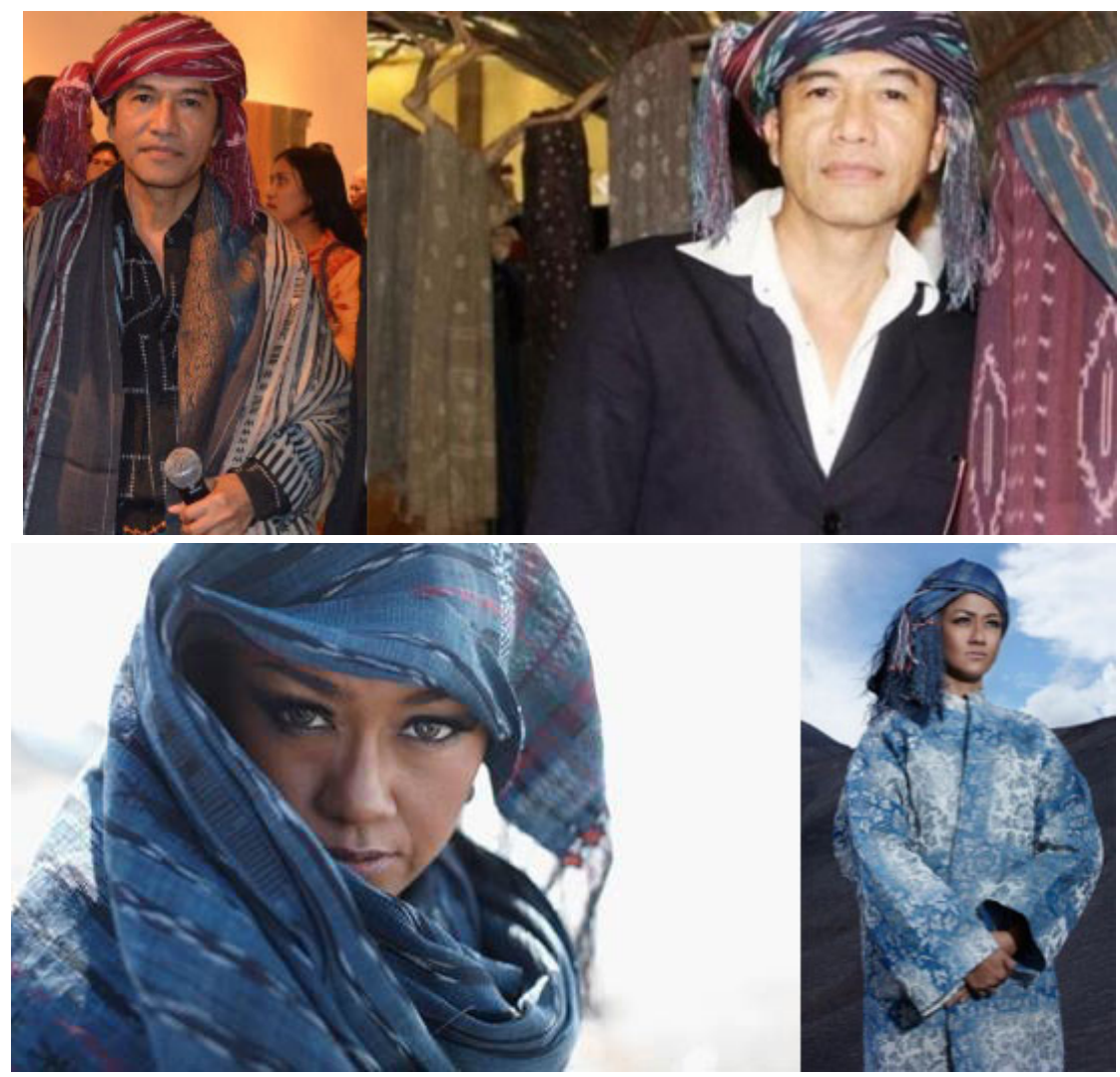

New fashion designs using cultural elements are bound to be superior due to their uniqueness not possessed by other nations. It is in such respect that the Copyright Law of 2014 provides significant protection to Indonesian nationals involving in the creative process of producing cultural heritage based products.

On a larger scale, IPR protection can allegedly provide incentive to creative individuals in creating new works which can potentially contribute to the enrichment of cultural elements. Such statement is supported by followers of the reward theory stated by, among others, Richardson as follows:

"Economic development and social welfare will be advanced if rewards are given for the kinds of invention and creativity that result in new products, processes and services". ${ }^{40}$

In the above quoted statement, Richardson expresses the view that the economy can be expected to develop and social welfare can be expected to become enhanced if creative individuals are compensated for their inventions and creativity. Such compensation is likely to motivate other creative individuals to be equally creative with the aim of achieving greater economic benefit, thus contributing to economic growth and social welfare. Followers of the reward theory do believe in this.

Based on the foregoing it can be inferred that a strong synergy exists between UUPK 2017 and IPR laws such as the Copyright Law of 2014, the Patent Law of 2016, and the like. However, such synergic relationship is bound to be void of any

${ }^{40}$ Benjamin J. Richardson, Indigenous Peoples, International Law and Sustainability, New Jersey: Blackwell Publishers Ltd., 2001, pg. 9. 
meaningful contents unless it is followed by strategic steps and real action towards its implementation. A beautiful symphony is on the verge of being created when the implementation of UUPK 2017 is supported by effective implementation of the Copyright Law of 2014 and the Patent Law of 2016 along with other IPR laws.

\section{G. Important Steps to be Undertaken}

UUPK 2017 places a greater portion of responsibility on the Government, central as well as regional, for taking concrete steps, particularly in the context of taking inventory of, developing, utilizing, preserving and promoting objects of the advancement of culture. Articles 43 and 44 of UUPK 2017 clearly articulate the tasks of the Central Government and the Regional Governments respectively. Such tasks include the following, among other things:

1) ensure the freedom of expression

2) ensure the protection of cultural expression

3) implement the advancement of culture

4) maintain diversity

5) manage information in the field of culture

6) provide cultural facilities and infrastructure

7) provide funding resources for the advancement of culture

8) promote the community's active role and initiatives in the advancement of culture

9) use culture as an international diplomacy media

10)enhance international cooperation in the cultural field, and

11) revive and safeguard a sustainable cultural ecosystem

All tasks mandated under the law to the Government serve as primary reference in determining measures for execution in practice. Some of them are specifically determined concrete measures. Let us take for example the task to implement the advancement of culture. As previously mentioned the advancement of culture includes activities of taking inventory of, developing, utilizing, preserving and promoting culture. It certainly needs to involve community members, which has been in fact set out as one of the tasks to be implemented by the Government.

The involvement of community members may very well result in the creation of individual creative works with IPR potentials. It means that the focal point of the implementation of UUPK 2017 does not solely rest with the relevant Ministry or agency dealing with culture related matters, but also with Ministries or agencies in charge of various other activities related to creativity, industry, trade, the protection of rights, particularly intellectual property rights, and the like. Accordingly, in the project of the advancement of culture the Government should become a harmonious symphony between the relevant ministries and non-ministerial agencies.

In the context of such symphony, it is expected that the orchestra of the advancement of culture will be able to render a solid performance. The relevant 
ministries or agencies include, among others, the following: Ministry of Education and Culture, Ministry of Industry, Ministry of Trade, Ministry of Law and Human Rights, and the Agency for Creative Economy.

One of the tasks mandated to the Government through the above mentioned ministries and agencies is providing financing resources for advancement of culture activities. ${ }^{41}$ It means that since the enactment of UUPK 2017, all of the aforementioned ministries are obligated to plan and allocate budgetary funds originating from the State Budget (State Revenues and Expenditures Budget).$^{42}$ The said budget planning and allocation process must naturally involve the Ministry of Finance which is in charge of budgeting related matters in the management of State finances. In the event that a ministry fails to undertake budget planning and allocation measures for the advancement of culture, it can be assumed that such ministry does not fulfill its mandate under the law as part of the executive body. In fact, the law sets out an even more specific funding mandate, namely by requiring the establishment of a culture trust fund (dana perwalian kebudayaan)..$^{43}$

Such funding is not to be used exclusively for the Government's own activities in implementing the advancement of culture; rather, it is also to be used in the context of providing facilities to community members who take the initiative to conduct activities for the advancement of culture. While the law does not set the limitation that funding can only be obtained from State Budget sources, it can at least be ascertained that by mentioning the State Budget, the funding of activities for the advancement of culture will be supported by State finance sources.

There is of course always the possibility that there would be in fact greater financing by the community itself, particularly in situations where the activities for the advancement of culture are supported by adequate private investment. For instance, activities for the utilization of cultural heritage in creative industries must certainly be implemented in an investment-based manner. In this matter, the Ministry of Industry, Ministry of Trade, and the Agency for Creative Economy play a vital role. The said ministries are posed to facilitate industry and trade oriented projects for the advancement of culture. At the same time, the Ministry of Law and Human Rights, the Directorate General of Intellectual Property in particular, can facilitate domestic small and medium scale industries whose business is based on the utilization of cultural heritage and creative industry in obtaining IPR.

An example of cultural heritage based industry is the batik industry. The said industry has been supported by raw materials such as fabric and coloring materials as a vital part of the development and utilization of the cultural element in the form of the art of batik. Due to such support, the batik industry has become heavily dependent on the import of certain products. In addition to the above, imported coloring materials are chemical based which produce waste polluting the environment. At

\footnotetext{
Article 48 paragraph (1) of UU PK 2017.

Article 48 paragraphs (2.a \& b) of UU PK 2017.

Article 49 paragraph (1) of UU PK 2017.
} 
the same time, natural coloring materials extracted from certain plants used to be utilized for batik in the past. It would be advisable for the Government to restore the environment friendly nature of the art of batik. In doing so, the Government could initiate the supply of raw materials for the batik industry by providing full support in investment projects for the production of mori fabric ${ }^{44}$ and agricultural projects for producing plants that provide natural coloring substances as well as to the manufacturing industry producing such coloring substances. Only by doing so would the batik industry become truly independent of imported products.

Such type of investment, however, is unlikely to be interesting to investors who generally strive to obtain the greatest possible profits within the shortest period of time possible. It is just the way business actors tend to behave. Therefore, the realization of the project of developing an independent batik industry is the Government's responsibility. UUPK 2017 offers a solution to the Government to start developing an independent culture based industry and to produce prime products for this Country. If the Government has felt that it has had no adequate legal basis for allocating budgetary funds for the advancement of culture thus far, the adoption of UUPK 2017 leaves no further excuse for it to avoid its Constitutional mandate, namely: to advance the Indonesian culture.

\section{H. Conclusion}

The final statement of the previous paragraph represents the most important statement namely that the Government can no longer avoid its obligation under the 1945 Constitution to advance culture. Symphonizing IP in the advancement of culture must be considered as a mega project with the obligation of its implementation being vested in the Government. The IPR concept which has been perceived so far as providing reward to creative individuals has gained momentum with the adoption of UUPK 2017. It is indeed achievable provided that the Government and the community join in a harmonious orchestra in implementing the above-mentioned laws and regulations.

We all hope for it to become reality.

\section{Bibliography \\ Books}

Agus Sardjono, Hak Kekayaan Intelektual dan Pengetahuan Tradisional, Alumni, Bandung, 2010.

Koentjaraningrat, Manusia dan Kebudayaan di Indonesia, Djambatan, Jakarta, 1988 Richardson, Benjamin J., Indigenous Peoples, International Law and Sustainability, Blackwell Publishers Ltd., New Jersey, 2001.

\section{Other Documents}

Hardi, "Pusaka Ksatria Nusantara Abad 21: Jangker", http://pelukishardi.com/jangker.

$44 \quad$ Mori cloth is plain white cloth used as the main raw material for producing batik. 
html\#.WIVypa6WbIU, accessed on 12 July 2017

Uni Sosial Demokrat, "Megalitikum Kuantum, Upaya Menemukan Kembali Indonesia”, http://www.unisosdem.org/article detail.php?aid=5082\&coid=3\&caid=31\&gid=2, accessed on 12 July 2017

Wikipedia about Dwiki Dharmawan, https://id.wikipedia.org/wiki/Dwiki Dharmawan, accessed on 12 July 2017

Badan Ekonomi Kreatif Indonesia, "Tugas Badan Ekonomi Kreatif Indonesia", http:// www.bekraf.go.id/profil/tugas, accessed on 12 July 2017

National Geographic, "La Galigo Kitab Sakral orang Bugis", http://nationalgeographic. co.id/berita/2012/06/la-galigo-kitab-sakral-orang-bugis, accessed on 12 July 2017

Anis Fuadi, "Merdi Sihombing Usung Kain Tenun Tangan Dari 9 Provinsi", https:// www.senayanpost.com/merdi-sihombing-usung-kain-tenun-tangan-dari-9-provinsi/, accessed on 13 July 2017

Nia Iman Santoso, "Merdi Sihombing, Desaner Tenun Ikut Ulos Indigo di AS", https:// www.voaindonesia.com/a/merdi-sihombing-desainer-tenun-ikat-ulos-indigo-di-as--liputan-feature-voa/1884459.html, accessed on 13 July 2017

\section{Legal Documents}

Law Number 7 Year 1994 concerning Ratification of the Agreement for the Establishment of the World Trade Organization.

Law Number 11 Year 2010 concerning Cultural Heritage.

Law Number 28 Year 2014 concerning Copyright.

Law Number 13 Year 2016 concerning Patent.

Law Number 20 Year 2016 concerning Trademark and Geographical Indication.

Law Number 5 Year 2017 concerning the Advancement of Culture.

Draft Law concerning Traditional Knowledge and Cultural Expression initiated by the Regional Representatives' Council of the Republic of Indonesia (DPD RI). 